UDC: $159.9+159.923 .3$

DOI: https://doi.org/10.24195/2414-4665-2017-7-21

\author{
Natalia Melenchuk, \\ PhD (Candidate of Psychological Sciences), teaching assistant, \\ Department of General and Differential Psychology, \\ South Ukrainian National Pedagogical University named after K. D. Ushynsky, \\ 4, Fontanska Doroha Str., Odesa, Ukraine
}

\title{
INDIVIDUAL PSYCHOLOGICAL PECULIARITIES OF ADVENTUROUSNESS ACCORDING TO EMOTIONAL TYPE
}

The paper deals with the peculiarities of adventurousness in persons with different types of emotionality. Emotionality is one of the psychological factors determining the adventurous behavior. The selection of this factor is due to the cornerstone impact of emotionality on the structure of personal qualities. The empirical research was based on Adventurousness Inventory (by O. Sannikova, O. Sannikov, N. Melenchuk) and Four-Modality Inventory of Emotionality by $O$. Sannikova. According to the research outcomes there have been found significant positive correlations with the "joy" and "anger" modalities, and negative ones - with the "fear" and "sadness" modalities. Besides, it has been revealed that people for whom the emotions of "joy" and "anger" patterns are more peculiar, are more prone to adventurous behavior, as compared to the persons with "fear" and "sadness" patterns. Emotionality affects the structure of adventurousness and determines its specificity.

Keywords: adventurousness, proneness to adventurous behavior, emotionality, factors, personal qualities, personality, qualitative analysis, quantitative analysis.

\section{Introduction}

The importance of studying the issue of adventurousness is caused by the requirements for a personality set by the changes taking place in the modern society. In particular, it is referred to the personality's qualities which help to achieve the goals set with the least possible troubles and time, moreover, instantaneously, without slow gradual actions. Proneness of a personality to adventurous behavior is just such a quality which can be considered not only as a negative phenomenon concerning the environment but also as a resource of creative decision-making which can either contribute to or prevent the adaptation processes in human life.

Sometimes "robust" (moderate and based on one's own desire) adventurousness can be useful. It is wellknown that lots of geographical discoveries have been performed by adventurers, for whom adventurousness is a lifestyle. Adventurous deeds provide an opportunity to change conventionalism with something new, achieve success [2, p. 113].

We understand adventurousness as a complex multileveled personality trait, whose psychological essence involves hoping for easy and fast success, good luck if there is a final goal which is desired for a person, without thorough analysis of real external circumstances, person's opportunities, ways of solving problems for achieving a goal $[1,3]$.

It should be noted that in real life such concepts as fraud, intriguety, affaire, and gambling are considered as synonyms, which is why "adventurism" is regarded as a kind of antisocial behavior. Though these notions should not be identified because they have different conceptual meaning. Thus, in the literature, "affaire" is understood as fraud, and "adventure" as a hope for success not based on the thorough analysis of a situation [3, p. 15]. It is these circumstances which create favorable conditions for adventurous actions.

Every person faces such a situation and manifests adventurous behavior, and very often, even succeeds. If he/she often acts like this, he/she can acquire the characteristics of the adventurous type of behavior, which is based on not only stable proneness to adventurousness but character traits which contribute to its manifestation and sometimes even act like its factors.

The studying of adventurousness is based on the continual and hierarchical approach by O. Sannikova $[4,5]$. Its use has made it possible to organize the theoretically explicated indicators of adventurousness into a complex multi-leveled quality which covers formal and dynamic, content and personal, as well as social and normative levels. Let us consider the structure of proneness to adventurous behavior, the manifestations of which at every level of the structure have their specificity.

The marks of adventurousness at the formal and dynamic level are manifested in the peculiarities of its emergence and pace, reflect the form of realization in various situations. At the content and personal level adventurousness manifests itself in the characteristics associated with personality orientation, his/her motivation sphere, values, worldview, interests, etc. The substantive aspects of adventurousness involve strength of motivation to manifest adventurous behavior, ability for its conscious regulation, personal readiness for this behavior, etc. At the level of individual experience, adventurousness is presented by the experience of adventurous behavior. At this stage, self-esteem of adventurous behavior, knowing the peculiarities of one's own opportunities, considering oneself to be an adventurous person are the components 
of adventurousness. At the socio-imperative level adventurousness reflects the system of knowledge about culture, religion, social environment concerning the manifestations of adventurous activity and deeds.

Based on the theoretical analysis of literature and previous empirical researches (questioning, analysis of compositions on the determined topic) we have revealed, explicated and described the components of adventurousness which form its structure. The formal and dynamic level involves energetic indicator of adventurousness, sensitivity to adventurous acts, the need for performing adventurous actions, initiative in proneness to adventurous behavior, wide range of adventurous activities, stable character of such a form of behavior. The qualitative level of person's proneness to adventurous behavior involves the following indicators: emotional and motivational (emotions which characterize the adventurousness), cognitive (ideas, thoughts, knowledge related to adventurousness), conative (external manifestations of adventurousness), control and regulative (ability to regulate the adventurousness manifestations). The content level is represented by the adjusting component of adventurous behavior.

The paper aims to reveal individual psychological peculiarities of adventurousness. The basis for studying individual differences in the manifestation of adventurousness was emotionality which being the most significant component of individuality determines stable specific attitude of a personality towards the environment $[4,5]$. Emotionality is considered as a character trait, as a basic factor of proneness to adventurous behavior.

The research hypothesis implies that adventurousness and emotionality are interconnected and people with different emotional dispositions are characterized with different levels of adventurousness.

It is known that emotions of different signs and modality differ from one another by the attitude to the object, which manifests itself in the sign of dominating emotions (positive or negative), orientation (at the object or against it), the way of interaction with an object (active or passive). Different emotional modalities are marked by different combinations of the defined characteristics. For example, emotions of "joy" modality have a positive sign $(+)$ which means positive attitude towards an object, active interaction with it and orientation at it; "anger" modality has a negative sign (-) which is manifested in negative attitude towards an object but active interaction and orientation at it (interaction and orientation are similar to joy); "fear" modality show negative attitude to an object, passive interaction with it and orientation against it; "sadness" modality have neutral or negative attitude towards an object, passive interaction and orientation against it [4, 5].

Considering the above mentioned it can be assumed that positive emotions will have positive correlations with indices of proneness to adventurous behavior, and negative emotions - negative ones. At this the level the dominating of one or another emotion and different individual combination of basic emotions will affect the specificity of adventurousness.

It should be mentioned that we investigate the impact of the very qualitative characteristics of emotionality which contain information about the modality and a sign of emotions, on the manifestation of adventurousness. The combination of these modalities, domination of one or several ones compose individually typological characteristics of emotionality of every individual and make it possible to explain relevant emotions of diverse nature and intensity, which arise in people in the same situations (in our case, in adventurous situations), as well as specificity of adventurous attitudes, ideas, behavior, etc. [4, 5].

\section{Research Methods}

In order to study indices of adventurousness we used Adventurousness Inventory which was developed by $\mathrm{O}$. Sannikova, O. Sannikov, N. Melenchuk according to the psychometrics requirements [1]. For examining emotionality, we applied Four-Modality Inventory of Emotionality by O. Sannikova [4]. The experiment was held in Ushynsky University and involved 382 students aged from 18 to 35 majoring in different fields of studies. The statistical processing of data was performed by means of SPSS 21.0 for Windows. Besides, we used correlation analysis and qualitative measurement.

\section{Research Results}

At first, let us consider the results of correlation analysis between the indices of adventurousness and qualitative indices of emotionality.

It should be noted that the modalities of joy $(\mathrm{J})$ and anger (A), as it was assumed, have significant positive correlations with the indices of adventurousness, and the modalities of fear $(\mathrm{F})$ and sadness (S) have significant negative correlations with the indices of adventurousness.

In particular, "joy" modality (J) positively correlates at $1 \%$ level with emotional and motivational (EMA), conative (CA), energetic (EA) indices of adventurousness and the general index of proneness to adventurousness (GA); at 5\% level - with the adjusting index of adventurousness (AA). Taking into account the psychological characteristics of the defined indices of adventurousness we can state that the modality of joy $(\mathrm{J})$ is accompanied by emotional arousal, feeling of satisfaction, being delighted with adventurous acts; courage, easiness of planning adventurous acts, etc.

We have obtained somewhat different results in the correlations of "anger" modality (A) with the indices of adventurousness which had significant positive correlations with the adjusting (AA) and energetic (EA) indices at $5 \%$ level; the index of sensitivity to adventurousness (SA) and general index of proneness to adventurousness (GA) - at $1 \%$ level. The presence of such correlations can be indicative of the complexity of the phenomenon of "anger" modality (A). This fact requires special attention and further studying.

"Fear" modality (F) correlates at $1 \%$ level with all indices of adventurousness. It shows the absence of proneness to adventurous behavior, to any manifestations of 
adventurous impulses in behavior.

The correlations obtained according to the modality of sadness (S) and indices of adventurousness in general are similar to the correlations of the emotion of "fear" modality (F), however, there are less significant correlations. In such a way, the modality of sadness (S) negatively correlated with emotional and motivational (EM) and energetic (E) indices of adventurousness at $1 \%$ level; with adjusting (AA) and general indices of proneness to adventurousness (GA) at 5\% level.

In order to examine individual and psychological characteristics of adventurousness of persons different in emotional dispositions using the qualitative measurement/aces method we allocated four groups of respondent with monomodal emotionality type: the ones with the modality of joy (J), anger (A), fear (F), or sadness (S) prevail- ing. As a result, the respondents were divided as follows: 31 persons composed a group of "J" emotional disposition, 16 people - "A" group, 17 respondents - "F" group, and 17 persons - "S" group.

Figure 1 presents the profiles of adventurousness of the distinguished groups. There are indices of adventurousness at $\mathrm{OX}$ axis, and their values in percentiles at $\mathrm{OY}$ axis. The median line goes through the point of 50th percentile. Every profile shows average values of the relevant indicators of the representatives of all distinguished groups.

Let us consider the profile of every group apart and then compare them. The arranging of indicators' values according to the departure from the median line has made it possible to describe individual psychological characteristics of the representatives of the groups (table 1).

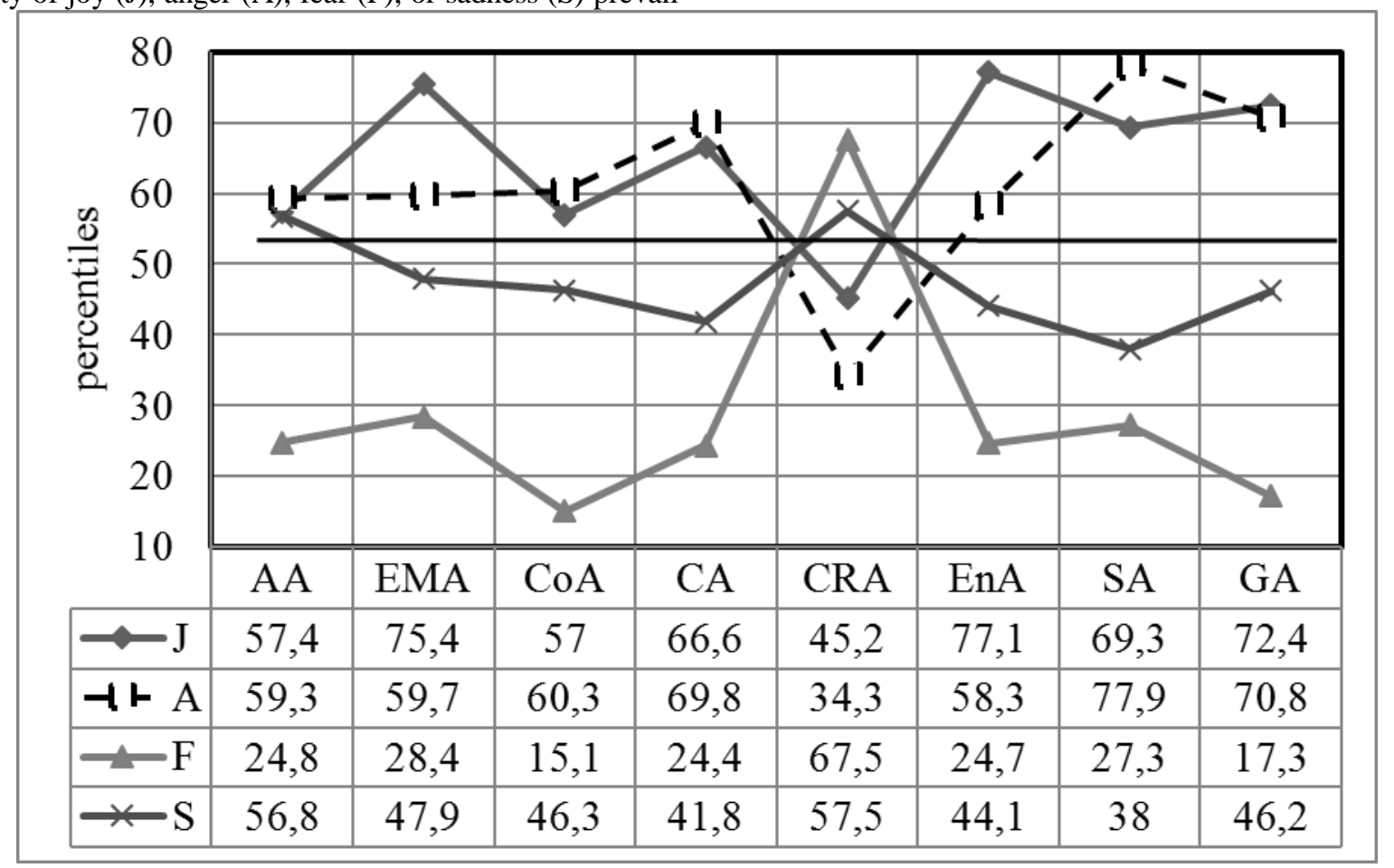

Fig. 1. Profiles of indicators of proneness to adventurousness of persons with monomodal emotional type

Note: 1) type codes of adventurousness indicators: AA - adjusting index, EMA - emotional and motivational index, CoA - cognitive index, CA conative index, CRA - control and regulative index, EnA - energetic index, SA - sensitivity to adventurous actions, GA - general index of proneness to adventurousness; 2 ) type codes of emotionality indicators: J - modality of joy, A - modality of anger, F - modality of fear, S - modality of sadness.

The representatives of $\mathrm{J}$-group are characterized by emotional arousal, spontaneity of emotional reactions, feeling of satisfaction which confirm the adventurous behavior (EMA+). Such people are energetic, active, vigorous, impulsive (EnA).

The respondents of A-group are marked by expressive movements, mimics, gestures, behavior, as well as by inadequate behavior focused on the achievement of the desired goal (CA+).

At the same time, the representatives of this group manifest sensitivity to adventurous situations (SA+) they easily answer their friend's suggestions concerning risky business, they are easily persuaded to take risky, unclear actions without a certain goal and without a plan of their realization.

Concerning F-group, its representatives are not prone to adventurous behavior (GA-). These people even cannot imagine themselves to be involved in adventurous acts. They are full of thoughts and ideas which block any manifestations of adventurousness (CoA-). The absence of proneness to adventurousness explains the absence of the external manifestation of adventurous impulses in their behavior (CA-). Some respondents of this group have shown the opposite behavior in order to demonstrate their 
"courage" which is considered as a challenge to everyone and themselves (EnA-).

Table 1

Predominant indices of adventurousness of the respondents different in monomodal emotional type

\begin{tabular}{|l|l|l|l|l|}
\hline \multirow{2}{*}{ Rank } & \multicolumn{3}{|c|}{ Groups of representatives of monomodal emotional types } \\
\cline { 2 - 5 } & J-type & A-type & F-type & S-type \\
\hline 1 & EnA+ & SA+ & CoA- & SA- \\
\hline 2 & EMA+ & GA+ & GA- & CA- \\
\hline 3 & GA+ & CA + & CA-; EnA- & AA+ \\
\hline
\end{tabular}

Note: "+" sign after the indices abbreviations shows high level of expressiveness of values, "-" sign shows the low level of values expressiveness.

Let us dwell upon the group prone to the emotions of S-pattern. Despite the fact the representatives of this group resemble the respondents of the F-group according to their characteristics, they manifest positive emotional attitude towards adventurous situations, and thoughts being a prerequisite of adventurous behavior are peculiar to them. The abovementioned means that the persons with the emotions of "sadness" modality prevailing can be considered to be prone to the emergence of adventurous behavior in an adventure-related (or neutral) situation $(\mathrm{AA}+)$. Similar to people of F-group, they are characterized by the absence of external manifestation of adventurous desires in behavior (CA-); they do not manifest sensitivity to adventurous situations and acts suggested by others (SA-).

The profiles of adventurousness of the representatives of J-group and A-group are located in a positive pole of the continuum which shows a general tendency for adventurousness, as distinct from F-group which is located in the space of negative values which is indicative of the absence of proneness to adventurousness. Concerning the profile of the representatives of S-group, it is located close to the median line but primarily in the space of negative values.

\section{Discussion}

The results obtained confirm the information available in literature stating that adventurousness correlates with positive emotions. For instance, I. Tymofeieva believes that "an adventurous person follows the conscious choice of activeness which brings pleasure and positive emotions" [6, 26-27]. J. Oldham and L. Morris note that the life of an adventurous person is fearless, which helps to conclude that there is a correlation between fear and adventurousness: the greater fear is - the less proneness to adventurousness a person has [7].

Therefore, we have considered profiles of adventurousness of every group of persons with a certain monomodal emotional type which has made it possible to study its specificity. In order to examine the level of differences divergences between the cognominal indicators of adventurousness of four defined groups we used Student's t-test (table 2).

Values of Student's t-test between the cognominal indices of adventurousness of people with a certain type of emotionality

\begin{tabular}{|l|l|l|l|l|l|l|}
\hline \multirow{2}{*}{$\begin{array}{l}\text { Indices of ad- } \\
\text { venturousness }\end{array}$} & \multicolumn{6}{|c|}{ The groups under comparison } \\
\cline { 2 - 7 } & $\begin{array}{l}\text { J-gr. / } \\
\text { A-gr. }\end{array}$ & $\begin{array}{l}\text { J-gr. / } \\
\text { F-gr. }\end{array}$ & $\begin{array}{l}\text { J-gr. / } \\
\text { S-gr. }\end{array}$ & $\begin{array}{l}\text { A-gr. / } \\
\text { F-gr. }\end{array}$ & $\begin{array}{l}\text { A-gr. / } \\
\text { S-gr. }\end{array}$ & $\begin{array}{l}\text { F-gr. / } \\
\text { S-gr. }\end{array}$ \\
\hline AA & 288 & $3.302 * * *$ & 0.653 & $3.202^{* *}$ & 0.262 & $-4.401 * * *$ \\
\hline EMA & 1.566 & $5.751 * * *$ & $3.442 * *$ & $3.181 * *$ & 1.8 & $-2.352^{*}$ \\
\hline CoA & 258 & $5.729 * * *$ & 1.729 & $6.671 * * *$ & 1.817 & $-4.03 * * *$ \\
\hline CA & 147 & $4.975 * * *$ & $2.31 *$ & $6.106 * * *$ & $3.173 * *$ & -1.139 \\
\hline EnA & 1.705 & $4.747 * * *$ & $2.86 * *$ & $4.786 * * *$ & 1.182 & $-2.045^{*}$ \\
\hline SA & -968 & $4.494 * * *$ & $2.613 *$ & $10.831 * * *$ & $5.949 * * *$ & -0.844 \\
\hline GA & 383 & $8.193 * * *$ & $2.842 * *$ & $10.714 * * *$ & $3.315^{* *}$ & $-3.506^{* *}$ \\
\hline
\end{tabular}

Note: type codes: 1) J-gr. - the group of people with "joy" as a dominant emotion, A-gr. - the group of people with "anger" as a dominant emotion, F-gr. - the group of people with "fear" as a dominant emotion, S-gr. - the group of people with "sadness" as a dominant emotion; 2 ) levels of significance: "*” is a sign of significant difference ( $p \leq 0.5) ; “ * *$ " and “***" are signs of significant differences ( $\leq \leq 0.01)$ and ( $\leq \leq 0.001) ; 3)+\operatorname{sign}$ before the value of Student's t-test means that this indicator according to the significance is greater in the first group, and -sign shows greater significance in the second group.

The analysis of table 2 shows that there are differences in the specificity of adventurousness in persons different according to emotionality and manifests signifi- cant divergences between all groups, except for $\mathrm{J}$ and $\mathrm{A}$, namely, between the group of the respondents with dominant emotions with a positive sign of "joy" pattern and the 
group with dominant emotions of "anger" pattern.

Thus, emotionality defines a structure of adventurousness (its specificity) and it is its main function. The research outcomes make it possible to consider emotionality as an important factor of adventurousness.

\section{Conclusions}

1. Proneness to adventurousness in this research is considered as a complex multi-leveled personality trait, whose psychological essence is manifested in the hope for east and quick success, luck without the thorough analysis of real external circumstances, one's own opportunities, ways of solving a problem in the process of achieving its goal.

2. We have examined individual psychological peculiarities of adventurousness in people different according to emotional disposition. We applied Adventurousness Inventory which was developed by O. Sannikova, O. Sannikov, N. Melenchuk. For examining emotionality, we applied Four-Modality Inventory of Emotionality by $\mathrm{O}$. Sannikova.

\section{REFERENCES}

1. Sannikova, O. P., Sannikov, O. I., Melenchuk, N. I. (2015). Psykhodiahnostyka avantiurnosti: Testopytuvalnyk skhylnosti do avantiurnosti [Psychodiagnostics of adventurousness: Adventurousness inventory] [in Ukrainian].

2. Ylyn, E. P. (2012). Psikhologiya riska [Psychology of risk]. Saint Petersburg: Piter [in Russian].

3. Sannikova, O. P., Sannikov, O. I., Melenchuk, N. I. (2016). Test-opytuvalnyk skhylnosti do avantiurnosti (AVANT-1): rezultaty aprobatsii [Adventurousness inventory: approbation results]. Problemy suchasnoi psykholohii: zb. naukovykh prats DVNZ «Zaporizkyi natsionalnyi universytet» - Problems of modern psychology: collection of scientific works of Zaporizhzhia national university (pp. 82-88). S. D. Maksymenko, N. F. Shevchenko, M. H. Tkalych (Ed.). Zaporizhzhia [in

\section{ЛІТЕРАТУРА}

1. А.с. Психодіагностика авантюрності: «Тестопитувальник схильності до авантюрності» (АВВАНТ-1); «Самооцінка компонентів авантюрності» / Ольга Павлівна Саннікова, Олександр Ілліч Санніков, Наталя Іванівна Меленчук. - Заявка № 60141 від19.03.2015; реєстрац. № 59701 від 15.05.2015. - 53 с.

2. Ильин Е. П. Психология риска / Евгений Павлович Ильин. - СПб.: Питер, 2012. - 288 с.: ил. (Серия «Мастера психологии»).

3. Саннікова О. П . Тест-опитувальник схильності до авантюрності (АВАНТ-1): результати апробації» / О. П. Саннікова, О. І. Санніков, Н. І. Меленчук // Проблеми сучасної психології: зб. наукових праць ДВНЗ «Запорізький національний університет», Інститут психології імені Г. С. Костюка НАПН України
3. The correlation analysis between the indices of adventurousness and qualitative indicators of emotionality has shown the presence of positive significant correlations with "joy" and "anger" modalities, and negative ones with "fear" and "sadness" modalities.

4. The analysis of profiles of adventurousness of the distinguished groups of persons has shown the similarity in its manifestations by the representatives of the groups with "joy" and "anger" as dominant emotions, and the opposite manifestations of adventurousness in the groups with "fear" and "sadness" modalities prevailing.

5. It has been proved that emotionality affects the structure of adventurousness: depending on the type of emotionality as a characteristics of individuality adventurousness has its specificity which manifests itself in qualitative and quantitative combination of its initial indices.

6. It has been established that the representatives of the groups with "joy" and "anger" patterns prevailing are more prone to adventurous behavior as compared to the persons with "fear" and "sadness" patterns prevailing.

\section{Ukrainian]}

4. Sannikova, O. P. (1995). Emotsionalnost $v$ strukture lichnosti [Emotionality in the structure of personality]. Odessa: Khors [in Russian].

5. Sannikova, O. P. (2003). Fenomenologiya lichnosti: Izbrannye psikhologicheskie trudy [Phenomenology of personality: selected psychological works]. Odessa: SMYL [in Russian].

6. Tymofeeva, Y. Yu. (2005). Avantiuryzm v russkoi kulture kontsa XVII - pervoi chetverty XIX veka [Adventurousness in the Russian culture of the end of the 17yjfirst quarter of $19^{\text {th }}$ century]. Candidate's thesis. Komsomolsk-na-Amure [in Russian].

7. Oldkhэm, Dzh. (1997). Uznay sebya. Avtoportret vashey lichnosti [Learn yourself. Self-portrait]. Moscow: Veche, Rypol Klassik [in Russian].

[за ред. С. Д. Максименка, Н. Ф. Шевченко, М. Г. Ткалич]. - Запоріжжя, 2016. - С. 82-88.

4. Санникова О. П. Эмоциональность в структуре личности / Ольга Павловна Санникова. - Одесса: Хорс, 1995. - 334 c.

5. Санникова О. П. Феноменология личности: Избранные психологические труды / Ольга Павловна Санникова. - Одесса: СМИЛ, 2003. - 256 с.

6. Тимофеева И. Ю. Авантюризм в русской культуре конца XVII - первой четверти XIX века: дис. ... канд. культурологических наук : 24.00.01/ Ирина Юрьевна Тимофеева. - Комсомольск-на-Амуре, 2005. $-151 \mathrm{c}$.

7. Олдхэм Дж. Узнай себя. Автопортрет вашей личности / Джон Олдхэм, Моррис Луи. - М.: Вече, Рипол Классик, 1997. - 185 с. 
Наталя Іванівна Меленчук, кандидат психологічних наук, асистент кафедри загальної та диференціальної психології, Південноукраӥнський національний педагогічний університет імені К. Д. Уиинського, вул. Фонтанська дорога, 4, м. Одеса, Україна

\section{ІНДИВІДУАЛЬНО-ПСИХОЛОГІЧНІ ОСОБЛИВОСТІ \\ АВАНТЮРНОСТІ, ЩО СПРИЧИНЕНІ ЕМОЦІЙНІСТЮ}

У статті розглядаються особливості авантюрності осіб з різними типами емоційності. Теоретично визначено, що емоційність виступає одним з провідних психологічних чинників, що детермінує авантюрну поведінку. Вибір саме цього чинника зумовлений системотвірним впливом емоційності на структуру властивостей особистості. Схильність до авантюрної поведінки (авантюрність) у цій роботі розглядається як складна багаторівнева властивість особистості, психологічна сутність якої виявляється у надії на легкий і швидкий успіх, вдачу за наявності кінцевої мети, яка $є$ принадливою для особистості, без ретельного аналізу реальних зовнішніх обставин, власних можливостей (ресурсів), шляхів вирішення проблеми під час досягнення цієї мети. Вивчення індивідуально-психологічних особливостей авантюрності здійснювалося в осіб, які розрізняються за емоційною диспозицією. Для емпіричного дослідження було застосовано оригінальний психодіагностичний «Тестопитувальник схильності до авантюрності» (АВАНТ-1) (автори: Саннікова О. П., Санніков О. І., Меленчук Н. І .) та «Чотирьохмодальнісний тест-опитувальник емоційності» О. П. Саннікової. Кореляційний аналіз між показниками авантюрності та якісними показниками емоційності показав наявність додатних значимих зв'язків 3 модальностями «радість» і «гнів», і від’ємних - із модальностями «страх» i «печаль». Аналіз профілів авантюрності виділених груп осіб показав схожість у проявах авантюрності у представників груп осіб із домінуванням емоцій модальностей «радість» $\mathrm{i}$ «гнів», і протилежні прояви авантюрності виявлено в групах осіб із домінуванням емоцій паттернів «страх» $\mathrm{i}$ «печаль». Доведено, що емоційність впливає на структуру авантюрності: в залежності від типу емоційності як характеристики індивідуальності авантюрність набуває своєї специфіки, котра виявляється у якісно-кількісному поєднанні їі вихідних показників. Встановлено, що представники груп осіб із домінуванням емоцій паттернів «радість» і «гнів» більш схильні до авантюрної поведінки, ніж особи із домінуванням емоцій паттернів «страх» $\mathrm{i}$ «печаль».

Ключові слова: авантюрність, схильність до авантюрної поведінки (авантюрності), емоційність, чинники, властивість особистості, особистість, кількісний аналіз, якісний аналіз.

Submitted on June, 19, 2017

Reviewed by Doctor of Psychology, prof. O. Sannikov 